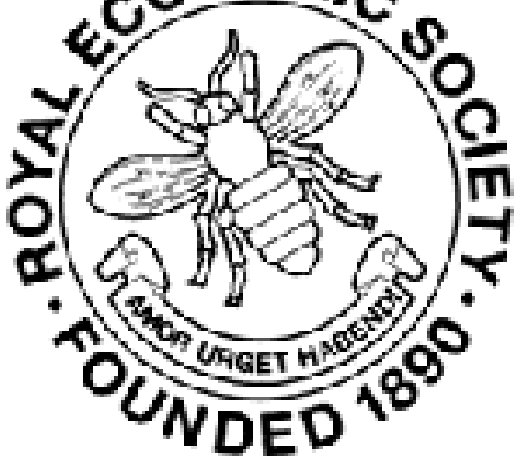

Mr. Wise's Industrial Arbitration Act

Author(s): W. P. Reeves

Source: The Economic Journal, Vol. 12, No. 47 (Sep., 1902), pp. 320-326

Published by: Wiley on behalf of the Royal Economic Society

Stable URL: http://www.jstor.org/stable/2956895

Accessed: 27-06-2016 07:14 UTC

Your use of the JSTOR archive indicates your acceptance of the Terms \& Conditions of Use, available at

http://about.jstor.org/terms

JSTOR is a not-for-profit service that helps scholars, researchers, and students discover, use, and build upon a wide range of content in a trusted digital archive. We use information technology and tools to increase productivity and facilitate new forms of scholarship. For more information about JSTOR, please contact support@jstor.org.

Royal Economic Society, Wiley are collaborating with JSTOR to digitize, preserve and extend access to The Economic Journal 


\section{MR. WISE'S INDUSTRIAL ARBITRATION ACT}

IN 1900 and 1901 organised labour was raising its head again in New South Wales. Its successive defeats in the Maritime Strike, and the other industrial wrestling bouts between 1890 and 1895, had taught it some valuable lessons without breaking its strength. It had also learned from the earlier mistakes of the labour members in the Colony's Parliament, where, after October, 1899, the Federal question ceased to complicate politics and hamper the labour party. About the same time the prosperity of the colony began to revive, after the depression caused by the great droughts. The time was opportune for a recrudescence of trade unionist activity and energy. Such a revival came, and with noteworthy results. The older unions recruited their forces and replenished their funds. New unions were formed. Thirty-four societies joined in the procession on Eight Hours Day in October 1901; three years before the number had been but twenty-five. Even the tailoresses were organised, and, after a series of strikes, obtained better conditions. There were also strikes of iron-workers, builders, wharflabourers, and other workers, and on the whole the settlements were favourable to the men. But the trade union leaders were not deluded by this into believing that strikes were the best means of bettering the standard of living. They had not forgotten the hard lessons of the past; they had been watching New Zealand; and they had made up their minds to transplant industrial arbitration to their own soil. In Parliament the alliance between the Labour party and the Government of Sir William Lyne was close, and it became closer and more fruitful after that gentleman's ministry was reconstructed under Mr. John See.

The labour members themselves did not essay the task of drafting an Arbitration Bill or piloting it through Parliament. If they had they might have failed. Certainly any such measure coming from them would have been eyed with something more 
than suspicion, and, even if passed by the Lower Chamber, might have been resisted to the last in the Upper. Fortunately, labour members knew their business too well, and were satisfied, as they well might be, to see the enterprise undertaken by Mr. Bernhard Wise, the brilliant barrister, who, after certain political adventures as lieutenant of Sir Henry Parkes, and after doing his share of the framing of the constitution of the Commonwealth, was now Attorney-General of New South Wales. Mr. Wise decided in 1900 to follow New Zealand's example; but he decided also to profit, if possible, by that colony's experience, and to avoid repeating the less happy portion of it. Moreover, he had the wit to see that a system moulded by the intense localism of New Zealand must, in some respects, be unsuited to highly centralised New South Wales. What was wanted was not a slavish copy but a free and skilful adaptation. It is in his statesmanlike endeavour to provide this that the main interest of Mr. Wise's Act lies.

Introduced into the Legislative Assembly in the middle of 1901, passed by that body, to be presently rejected by the Council, the Industrial Arbitration Bill of New South Wales then ran the gauntlet of a general election. When the See-Labour alliance carried the country, the Council's resistance broke down, and the Bill was allowed to go through. The only important concession made to the Upper Chamber was that the law should have force only until the beginning of 1908 . With that proviso it was adopted, and was assented to by the Governor on 10th December, 1901.

Its difference from the New Zealand Act begins with the title. In that the word "conciliation" is not found. After much debate the Parliament of New South Wales resolved to strike out any suggestion of a conciliation board, resolving that their arbitration court should not be a final tribunal merely, but should do the whole work of the law. The judge and two assessors composing it are to be paid $£ 750$ a year each, with travelling expenses. The assessors are to be elected for three years by bodies of delegates representing unions of employers and trade unionists respectively. During their term of office they may be removed only on account of bankruptcy or insanity, or in such manner as a judge of the Supreme Court may be removed.

The disputes to be arbitrated, upon are every sort of difference likely to arise between organised labourers and employers. The employers may be organised or not; the labourers must be. The labour societies may be registered under the Act or be ordinary No. 47.- VoL. XII. 
trade unions. Mr: Wise avoided the trap into which the West Australian law-makers fell in 1900 when they confined the jurisdiction of their industrial tribunals to conflicts in which unions registered under their Arbitration Act were concerned. No New South Wales trade union can remain outside the Act by neglecting to register under it. The Court may oite any trade union before it and may include it in any award. By registering, however, the trade union becomes an industrial union able to vote in the election of the labour assessor of the Court. As in New Zealand, an industrial union is to be a corporation with a common seal, entitled to possess and deal with real and personal property:

Nothing in the Act is to render any industrial union liable to be sued, or to have its property or its members' property taken in execution, otherwise than in pursuance of the Act itself, "or in respect of obligations incurred in the exercise of rights and powers conferred by this Act." No identical proviso is found in the New Zealand law, though in clause 7 thereof it is enacted that though a registered union becomes a body corporate, it does so "solely for the purposes of this Act." Only a trade union may register as an industrial union under Mr. Wise's Act, another departure from the New Zealand system. Unorganised work-people will therefore have to go through a double process of registration. In allowing non-unionist workers to organise and register under the New Zealand Act, its framer not only wished to avoid this and to attract hitherto unorganised labour, but desired to meet the charge so constantly made against him of conspiring with the labour leaders to limit the advantages of his law to a few close corporations in the shape of existing trade unions. He also thought it well, perhaps, that the new unions should be cut off from the trade unionism of the past with its militant traditions. Mr. Wise was in a different plight. His problem was not how to tempt apathetic or suspicious unionists to renounce strikes and utilise arbitration. He had to contrive to prevent labour from overdoing arbitration and irritating the public by bringing too many cases into court. The use of his law, therefore, is a privilege given to trade unions, who to acquire the full privileges given by it must register under it. To provide that the unions shall not be shams, the registrar appointed under the Act may insist that union officers shall see to the levying of subscriptions, fees, and penalties from the members, and that the accounts shall be fully and truly kept.

Employers are also invited to form and register industrial unions. As the individual employer is considered to be the 
equivalent unit to a trade union, a single employer, firm, or company may register as a union. Any person or association who does this must have employed not less than fifty workers, on the average, during the last six months before applying to the registrar.

Not only are strikes and lock-outs prohibited during the reference of any dispute to arbitration, but persons who strike or lock-out after a dispute has arisen, before giving reasonable time for an application to be made to the Court, are guilty of a misdemeanour. The punishment for this is a fine up to $£ 1,000$, or imprisonment for not more than two months. In New Zealand the penalty is a fine merely, and that must not exceed £50. In New South Wales, henceforth, any employer who dismisses a worker for belonging to a union, or because he or she is entitled to the benefit of any award of the Court, is liable to be fined $£ 20$. No proceedings under this section (35) of the Act are to be begun without leave of the Court; but when they are begun, the onus is to lie on the employer to satisfy the Court that the dismissal was owing to some other than the alleged reason.

In its procedure the Court is to be as unfettered as that of New Zealand, and, like that, may not be appealed from. It would seem, however, that in New South Wales either party may please itself as to the employment of counsel. The precautions against disclosure of trade or business secrets are emphatically worded. Only an order of the president can compel any party to produce account books. These can only be inspected by the members of the Court, unless the owner consents to let any one else see them ; and the members of the Court are sworn not to divulge their contents under penalty of dismissal from office. Evidence as to trade secrets and profits must be taken in camera, if the parties affected thereby so desire. Generally the Court has power to hear any matter in private, and, as in New Zealand, may receive evidence whether technically legal or not, is specifically granted the power to fix a minimum wage, and may order any employer to give preference to unionists over nonunionists, "other things being equal," when men from both classes offer their labour at the same time. There is the New Zealand power in the Court-when an industrial dispute involves technical questions-to appoint two assessors to sit with it, selecting them, one from the side of capital, the other from labour. Any technical matter may also be referred specially to an expert, whose report shall be accepted as evidence.

Perhaps the Act's most interesting feature is the "common rule." This is an effort to improve upon the tentative New 
Zealand method of extending the regulative scope of their Court decisions, so that, instead of merely binding specific employers, they are made rules virtually dealing with whole industries. The New Zealand plan has been to proceed through district after district, citing all the employers in the industry under review in each; then, after an award has been given, any one subsequently entering the trade had to be cited too, unless he was prepared to comply with the award voluntarily. In 1900 the scope of awards was extended so as to bind, without further proceedings, any one who during their currency should enter any industry regulated by them. Power was also given the Court to extend an award so as to include any employer or union not a party thereto, but engaged in the same industry as that to which the award applied. A moment's reflection will show that, under these successive extensions of its power, the Court was enabled to lay down rules affecting a whole industry. In effect this has been done, though the Court has taken province after province in the gradual fashion made almost necessary by the sharplydefined subdivisions of the colony. Moreover, in New Zealand there has been a strong prejudice against regulating the businesses of employers who have not been at least invited to attend the hearing of the case affecting them.

In New South Wales, however, the Court is to have power to treat any award as a test case, and to apply the award therein to. the whole industry throughout the colony. It may, so to speak, give an award in rem, instead of in personam, as is done in New Zealand, where employers must be named specifically. It may declare that any custom, regulation, agreement, condition, or dealing whatsoever in relation to any industrial matter shall be a common rule of the industry. It may also limit the area within which the rule shall be operative, and may allow exceptions to it. As in practice it will probably both limit areas and allow a good many exceptions, the net result will probably be very similar to that secured under the New Zealand plan. I think this more especially likely, because under clause 38 of $\mathrm{Mr}$. Wise's Act, any person affected by an award may apply to the Court to be relieved of any obligation thereunder. On paper the New South Wales method looks to be a short cut to the goal which in New Zealand has to be reached more slowly and tediously. In practice we must wait to see to what extent the Court in New South Wales has to fix limitations, allow exceptions, and deal with protests of individuals and localities. In any case, Mr. Wise's common rule is an experiment to be 
watched. If successful, it may tempt the New Zealanders to simplify a portion of their law, and lead the Victorians to develop their good but imperfect system of wages boards into something more like the industrial arbitration of the other two colonies.

In New South Wales, as in New Zealand, the highest penalty that may be inflicted on an employer or union for breach of an award is $£ 500$. Small as such a sum may seem, it has never been found needful to impose any penalty nearly as heavy to enforce the awards of the New Zealand Court. A peculiarity of $\mathrm{Mr}$. Wise's law is that it does not follow the example of the other in limiting the currency of awards to three years. On the face of it, they may be made for an indefinite term. When, however, we turn to the sections of the law dealing with industrial agreements - that is to say, written contracts made between industrial unions and employers and registered under the Act-we find that the New Zealand method has been exactly copied. Agreements may be entered into for any time not exceeding three years, and thereafter are to remain binding until one month's notice in writing is given by a party wishing to vary or end them. It is plain, then, that the framer of the New South Wales law contemplates awards which take the shape of an order of the Court directing both sides in a dispute to enter into an industrial agreement. This is commonly done in New Zealand, where it has been found a convenient method of showing disputants where they are.

Four words in clause 26 of the Wise Law may lead to interesting incidents. In addition to the jurisdiction given to the Court to hear industrial disputes referred to it in pursuance of the Act-that is, I presume, by one of the parties to the quarrel -it may determine " any industrial matter referred to it by an industrial union or by the registrar." One would have expected to read the words "or by an employer." Passing from that point, I shall be curious to note what use will be made of this power given to the officer of the Arbitration Court-an officer who will be departmentally a subordinate of the Attorney-General - to initiate proceedings under the Act. The clause looks like a design to compromise between the New Zealand plan of leaving the initiative entirely to one or other disputant, and the Victorian of looking to the wages boards, factory inspectors, and the chief secretary to set the machinery in motion-indeed, to do everything. Mr. Wise has said frankly that he does not see why the Arbitration Court should not, through its registrar, intervene 
in a dispute, though none of the parties thereto care to invoke it. He thinks combatants who are bringing an industry to a dead stop should be regarded as brawlers in a street who check traffic with their quarrelling: they should be made to move on. This is good sense. One does not, however, envy the judge who has to arbitrate between two sets of embittered disputants, neither of which desires his intervention. Judging, too, from the experience of New Zealand the last thing to be feared under a system of industrial arbitration is an unwillingness on the part of the disputants to set the machine in motion. What little experience we have already had of the New South Wales Act goes to confirm this. Already the Arbitration Court in Sydney is besieged with applications for hearings, and the President has had to protest against an ugly rush of cases.

Though not yet twelve months old Mr. Wise's Act has ceased to be the newest arbitration law in the colonies. The West Australians, finding their Act of 1900 defective, decided not to amend but to repeal it. Accordingly, in February, 1902, they superseded it by a new statute following more closely the New Zealand model. It is noteworthy that they retained Conciliation Boards despite the example set by New South Wales.

There are now five laws at work in the Commonwealth and New Zealand under which wages and the conditions of labour may be regulated. In New South Wales, in New Zealand and in Western Australia Compulsory Arbitration laws are in active operation. The Victorian system of Wages Boards is in use in Melbourne and Adelaide. The student, therefore, will have five analogous experiments to watch and judge during the next few years. At the time of writing this the Act of New South Wales and the new law of Western Australia are too young to be of use as tests. In South Australia, too, the minimum wage is as yet a novelty which has been sparingly employed. The New Zealand and Victorian laws, however, have been fully. used, the former for nearly seven years, the latter for about five. These two statutes, therefore, already yield material for study and comparison.

W. P. REeves 